\title{
The Islamic Terms Translation in Kalimatun Sawa' an Indonesian Bulletin
}

\author{
M. Agus Suriadi \\ English Litters Department \\ Syarif Hidayatullah State Islamic University Jakarta Indonesia \\ magussuriadi@uinjkt.ac.id
}

\begin{abstract}
This research study aims to find out how the Islamic terms on the source text (ST) dealing to the target text (TT) English language- with same sense and meaning. It is analyzed qualitatively by using some translation strategies considered as linguistic approach and semantic approach. The data were obtained from Islamic terms taken randomly from a bilingual bulletin existed in Indonesia. From linguistics side, it found 3 data of borrowing, 1 data of transposition, and adaptation is 0 data. Meanwhile, from the semantic side, it found 5 data of modulation, 3 data of emphasis change, and 0 data of paraphrase. as the result, the most approach used to deal the meaning of the terms is semantics one. However, those approaches influenced to the transferences which were not successfully conveyed the real meaning to the informants. They who are common to the Islamic terms and otherwise got difficulties to unsderstand the transference, because the approaches were used still oriented to the word-form not to the meaning one. Semantic approaches as the meaning oriented is suggested to be considered to do transferring; however, the use of it in not right terms will be resulting in a missing link information originally contained in ST. Hence, it is important for the translators not only understand the approaches, but also use it and communicatively transfer the meaning by giving note as the way to inform clear context to the target readers and also give some note in the terms translated by the transaltors.
\end{abstract}

\section{Keywords-- Translation Approaches, Linguistics, Semantics, Transposition, Borrowing, Naturalization, Modulation, Paraphrase, Emphasis Change}

\section{INTRODUCTION}

There are many kinds of terms exist in any kinds of text, from mystic terms, scientific terms, and also religious terms [1]. Those all could notbe provided in the target text when they are translated. That is why, we need to use some strategies to deal the source text to the target text without missing the information contained in the source text. Moreover, the translation that has been done in the big frame can involve two approaches, namely linguistics and semantics.

Research studies have discussed about translation of terms; one of them is the study done by Khosroshahi and Sedighi [2]. They discussed about Persian Mystic translation strategy used by the translator. The result showed that $72.41 \%$ of the translation result used literal translation strategy and $68.96 \%$ used direct transfer procedure. Literal translation strategy was the most frequently used. This research focused only to the strategy mostly used by translators.

Meanwhile, the other research discussing about terms also has been done by Hasan [3]. In this research, he only focused on the classification of different types of semantic translation. He did his research by doing some surveys to analyze two kinds of translation proposed by Peter Newmark, semantic and communicative translation, and the using of it in the translation of scientific texts. The data were taken from the translation of Scientific American (Arabic Edition) and using semantic translation, communicative translation, and a combination as the instrument analysis. The translation heavily used gloss in the target terms. This was due to scientific term that needs more clarification. He argued that the using of gloss translation that typed as semantic equivalence or formal equivalence, where form and content are reproduced to address the specialized reader. As the conclusion, communicative method on translation is more suitable for scientific texts.

The last, the research also discussing about terms translation were done done by ElShiekh and Saleh [4]. They used statistical evidence to decisive and not decisive regarding to the negative/positive effect of the use of transliteration upon the addressees. This research resulting that the using of transliterated religious terms rather than the translation reflection.

From those studies, they were only analyzing on the translation approach used and the most frequent strategies that appeared. So, this research aims not only classify to the strategy used and most appered, but also explore how the terms on the source text (ST) deal to the target text (TT) - English language - with same sense and meaning through the responses of the target readers (informants) to the translation results by who are basically known about Islamic terms and otherwise. It is analyzed qualitatively by using some translation strategies: linguistic approach (transposition, borrowing, naturalization) and semantic approach (modulation, paraphrase, and emphasis change) as the instruments.

Munday stated that the main discussion of translation is linked to the form and content strategies [5]. The form considered as translation oriented to the formal and linguistic replacement. So, commonly strategy used resulting the translation which are still cannot convey the meaning clearly to the target readers or in other statement considered as the faithful translation, where the translator did their work still concentrated to the ST. Further, the other one can be considered as the communicative approach, where the translator attempts to find communicatively the target text with the meaning that is equivalent and can be accepted by the target readers. Those can be categorized into the linguistic and semantic approaches.

The transference which replacing on the grammatical structure of the TT transferred to the ST. Although this one is not communicative enough, however in some cases it works. On the other hand, it presents as syntactic strategy or as literal translation 
[6]. There are many ways that can be used to deal with a good translation. In this study those considered as the linguistic approach, those are: The first is transposition, it defined as the changing of grammatical pattern from source language into target language or shift. It refers to any transferences in the word class or approach [7], for example: ST: Is this seat taken? > TT: Bangku ini ada yang punya?. In this example, occurring transposition in the linguistic approach where verb (taken) changes to be adverb (ada yang punya) into Bahasa Indonesia. Transposition involves a change in the grammar from SL to TT. For instance, the changing of singular to plural is required when a specific ST structure does not exist in the TT. It also happened in any levels of the words, such as the changing from verb to noun, from plural to singular, and so. Those are can be happened base on the target context.

The second is borrowing or loan word; here the word transferred directly to another language. It is a process of morphological importation involving no morphological replacement but with or without substitution phoneme [8]. These importations do not imply grammatical change. It can be included the borrower adopted the pronunciation and spelling from original word. For the example: ST: hamburger > TT: hamburger. From the example, it occurred morphological importation involving no morphological replacement, where burger $=$ burger in target language (Bahasa Indonesia).

The third is adaptation. It is a way to transfer and adapt the ST to the normal pronunciations, then to the normal morphology of the TT [9]. It can be considered as a word-form translation where the translator replaces the structure of the SL to the TL. The translator must also create a new situation which has equivalence, modifying the concept but it is not beyond the purpose. For the example: TT: Governor > TT: Gubernur. This example shows that governor is adapted to become gubernur into Bahasa Indonesia, with normal pronunciation then to the normal morphology of the TT.

The second approach is semantics. The strategory categorized into this approach, the first is modulation. It is a translation strategy that supposes to explain the meaning, to obtain the relation meaning between ST and TT and also to achieve the equivalence meaning as natural as ST [10]. It occurs when a word or phrase is translated differently as a word as a meaning itself. For the example: ST: enhanced > TT: dilengkapi. The literal meaning of enhanced is dipertinggi in TT (Bahasa Indonesia), but in the transference is translated into dilengkapi. It is because the translator tries to obtain meaning between ST and TT.

The second category is paraphrase. this strategy is explaining much more detailed to create a liberal approximate translation; some lexical items may be ignored [11]. Here the translator uses his understanding of the ST to interpret the message by explain it with more explanation or long descriptive text, for the example: ST: the light is red > TT: pengemudi kendaraan berhenti. It is time for the driver to stop their vehicle. The example shows that the translator did the transference by using a long descriptive text to give more detail about the information contained in the SL. The last is emphasis change. Here the translator did the increases, decreases, or changes the emphasis of thematic information of ST [12]

\section{METHODS}

This is a qualitative method where the data have been collected in order to find the information and conclusion with verbal description [13]. The data were analyzed by applying the theory about translation strategies that considered here as the approaches of translation to define an equivalent effect from the source terms to the target terms that transferred into English.

The data were taken from the Kalimatun Sawa' Bilingual Bulletin Vol. 01, No. 01 [14]. This bulletin is published by Pusat Studi Budaya dan Perubahan Sosial, Universitas Muhamadiyah Surakarta - Indonesia, as the unit of analysis. The instruments of this research is the researcher himself and the informants. To do that, firstly the data classified as the Islamic terms randomly considered into faith terms, acts of worship terms, law and jurisprudence terms, or cultural terms [15]. The data were collected by using note taking technique and put those in the table. After that, comparing the terms translation result into linguistic or semantic approaches of ST and TT. Then, the context of the texts were asked to the informants with in-depth interviews to who understand- well about Islamic terms and otherwise. The data validation is done by doing triangulation to the 10 different informants. The triangulation data will be used as the data indicating to the quality of the translation. Finally, it progressed to the discussion between the theories and the data and then draw conclusion.

The research questions are formulated as follow: first (Q1), what approach both in lingustics and semantics are dominantly contained on the translation result of the target text?; second (Q2), Are the approaches used influence to the meaning equivalance in the translation result of the target terms?; Third (Q3) How do those approachs affect to the undestanding of the readers who have basic knowledge about Islamic terms and otherwise?

\section{RESUlTS AND DiscUSSIONS}

A good translation conveys not only the form, but also the message. If the consideration is hard to do, semantic strategy can be an alternative as a solution to transfer the information or message from the ST. The semantic recognised equivalency between two situations [16]. The strategies that can be considered are modulation, paraphrase, and emphasis change. In the actual practices, not only appropriate approach must be used, but also the right strategy will be considered to result the accurate transference of the terms. That's why, the translation needs to understand about the background or culture of the words or terms appear. So, even the semantic has considered as the approaches to deal with the meaning; however the appropriate one will affect to the transferring results, as follows: 
TABLE 1

SOURCE TEXT, TARGETB TEXT, LINGUISTIC APPROACH

\begin{tabular}{|c|c|c|c|c|c|c|c|c|}
\hline \multirow[b]{2}{*}{ DATA } & \multirow[b]{2}{*}{ ST } & \multirow[b]{2}{*}{ TT } & \multicolumn{3}{|c|}{ LA } & \multicolumn{3}{|c|}{ SA } \\
\hline & & & $\mathbf{T}$ & B & $\mathbf{A}$ & M & $\mathbf{P}$ & EC \\
\hline 1 & Kalimatun sawa & similar words & $\sqrt{ }$ & $\mathrm{X}$ & $\mathrm{X}$ & $\mathrm{X}$ & $\mathrm{X}$ & $\sqrt{ }$ \\
\hline 2 & hikmah muta'aliyah & Hikmah muta'aliyah & $\mathrm{X}$ & $\sqrt{ }$ & $\mathrm{X}$ & $\mathrm{X}$ & $\mathrm{X}$ & $\mathrm{X}$ \\
\hline 3 & as-sabiqun al-awwalun & the experience of the predecessors (assabiqunal awwalun), & $\mathrm{X}$ & $\mathrm{X}$ & $\mathrm{X}$ & $\sqrt{ }$ & $\mathrm{X}$ & $\mathrm{X}$ \\
\hline 4 & asbab an-nuzul & terms of its historicity & $\mathrm{X}$ & $\mathrm{X}$ & $\mathrm{X}$ & $\sqrt{ }$ & $\mathrm{X}$ & $\mathrm{X}$ \\
\hline 5 & mufassirun & the classical interpreters & $X$ & $\mathrm{X}$ & $\mathrm{X}$ & $\sqrt{ }$ & $\mathrm{X}$ & $\mathrm{X}$ \\
\hline 6 & al-qira'ah al-muntijah & the sophistication of productive hermeneutics & $\mathrm{X}$ & $\mathrm{X}$ & $\mathrm{X}$ & $\mathrm{X}$ & $\mathrm{X}$ & $\sqrt{ }$ \\
\hline 7 & mubahalah & mubahalah & $\mathrm{X}$ & $\sqrt{ }$ & $\mathrm{X}$ & $\mathrm{X}$ & $\mathrm{X}$ & $\mathrm{X}$ \\
\hline 8 & jizyah & jizyah & $\mathrm{X}$ & $\sqrt{ }$ & $\mathrm{X}$ & $\mathrm{X}$ & $\mathrm{X}$ & $\mathrm{X}$ \\
\hline 9 & tahqiq & a confirmation (tahqiq) & $\mathrm{X}$ & $\mathrm{X}$ & $\mathrm{X}$ & $\sqrt{ }$ & $\mathrm{X}$ & $\mathrm{X}$ \\
\hline 10 & istiqamah & to keep oneself committed & $\mathrm{X}$ & $\mathrm{X}$ & $\mathrm{X}$ & $\sqrt{ }$ & $\mathrm{X}$ & $\sqrt{ }$ \\
\hline
\end{tabular}

Data $=$ number or data; $\mathrm{ST}=$ Source Text TT $=$ Target Text LA = Linguistic Approach; SA = Semantic Approach; $\mathrm{T}=$ Transposition B = Borrowing; $\mathrm{A}=$ Naturalization; $\mathrm{M}=$ Modulation; $\mathrm{P}=$ Paraphrase $\mathrm{EC}=$ Emphasis Change.

The table data 1 shows that kalimatun sawa' as ST was transferred into "the similar words". "kalimatun sawa" is derived from Arabic that has a meaning of "the accord" or "the meeting point". Here, the ST translated into "the similar word", where from the theory mentioned above, it was categorized into transposition. Because it concerns to the form only; kalimatun = word and sawa = similar. And if it looked to the semantics, it categorized into the emphasis change where the translator increase the meaning between SL and TL to become general idea. Those approaches influence to the transfer has been made not accepted with the international term, where in the world interfaith it common that term with "the common word". So, modulation has made impacting to not common acceptence to the international term about kalimatun sawa itself, where it familiars with "common word". Futher, from 10 respondeses, 7 of them responded by over "common word" as the acceptance transference. And the others, accept it as the terms which have similar definition to the source terms.

On the data 2, hikmah muta'aliyah was translated to hikmah muta'aliyah too. This transfer fulfills the category on linguistic only, borrowing, because it is loanword where the process of morphological importation involving no morphological replacement without substitution phoneme. So, it impacted to the audience or the reader who were asked, especially who do not understand any kinds of Islamic term, 6 respondence did not understand to the information has transferred. Even to the audience who know a bit about it. It happended because there is no supporting information to understand the information contained in source text, such as a note.

On data 3, as-sabiqun al-awwalun was translated into "the experience of the predecessors". It considered into no one category in linguistics one. It because the transference has made trying to replace a social, cultural, or reality in the source text with a corresponding reality in the target text. Meanwhile, from the semantic one, it considered as modulation. Because the translator tried to transfer not only a "form" but also gives a point of view to the reader with the information that has a relatively close with the source text. As- sabiqun = generation and al-awwalun = predecessors (people who live in Prophet Muhammad era). Those considered because "experience generation" refers to the person who lived in prophet era. Base the informants were asked, 8 corespondenses to the context of meaning responding with undertand of it. So, can be considered that the transference was successfully delivered. Further, it can be understood by the readers, because the meaning has a close context with the meaning that informants understands.

On data 4, asbab an-nuzul was translated into "terms of its historicity". If it is looked literally, $a s b a b=$ caused of something and $a n-n u z u l=$ down. The meaning transferred considered into no category of linguistics category. Even though, it was not really close meaning. However, as a form it considered accepted in the target reader. Moreover, in the semantic category considered into modulation because the target (terms of its historical) transferred in 
the point of view of the reader from the meaning. And semantically, it refers to the meaning that be understood by reader as impact of it. Further, it supported by 10e informants were asked, 9 of them are undertand to the transference that has been made.

On data 5, mufassirun was translated into "the classical interpreters". If looked from linguistic approach, it goes to one of them. Because "the classical interpreters" replace the people who are expert in Qur'an and hadiths and also able to interpret the contextual meaning base on the cause of its down. In the semantic category, it considered into modulation. Because, even though mufassirin understood as someone who not only expert in Islam and try to interpret the holy Qur'an who are not only coming from classical era, but also currently and all days. as long, they have capacity and fulfilled the conditions has been considered among the Muslim scholars. However, the contemporary Muslim scholars who has capacity and ability to interpret the Qur'an, never declare themselves as mufassirun. So, supported by the informants were interviewed, 7 of them are understand it as a good works. Because the word "interpreter" is understood not only as someone who interpret the foreign language, but also interpret the message from the God.

Rahmatan lil 'alamin in the table 6 has a meaning of blessing for the whole world and its content or blessing for all mankind. In the target term, it was transferred into "universal humanity" which is "universal" means effecting or done by all people or things in the world or in a particular group. Meanwhile, the word "humanity" has a meaning as the human race or human beings collectively. Further, "universal humanity" can be transferred as "all the group of people in the entire of the world". However, this transferred for the informats were aksed din not missing link the meaning of the target term. Because it still has same information to the source. So, this transference is categorized into emphasis change in semantic category because it emphasis from the source form but has same meaning to it. It is also supported by the informants; 8 of them recognized the universal humanity as the values accepted by whole entire of the humankind in the world as blessing for the world (rahmatan lil 'alamiin).

On the data 7 shows Mubahalah in ST was translated into mubahalah too in TT. In linguistics approach, it is categorized into borrowing, because the word of mubahallah transferred into mubahallah where the process of morphological importation involving no morphological replacement without substitution phoneme. Meanwhile, in semantics approach are not categorized into any one of it. Because the transferring only focus to the form, so it resulted an unclear information for the readers. It supported by the informants were interviewed. 5 of them not understand to the results. Meanwhile the others were understand but they need to need the context of the text. So, this is still average a good enough translation. It will be better if the work done by giving note or explanation with parentheses after it. One of alternative can be done as follow mubahalah (withdrawing mercy from one who lies or engages in falsehood). By giving explanation the readers of TT will understand what the information means.

The unclear transferred also happened on table 8, jizyah translated into Jizyah without substitution phoneme and also without explanation inside. It is categorized as borrowing in linguistics one. Further, in semantics are not categorized into any one of it. it effected to the unclear information conveyed to the readers of TT. It is also supported by the informants were interviewed, 9 of them can not recognized to the transference has made. Because not all the reader know or understand the meaning of transferring term. That's why, will be better in this work also giving a note or explanation by giving parentheses. So, as the alternative can be done as follow: jizyah (personal tax). By giving it, the reader will understand the information containing in the ST.

The transferred on the data 9 is considered as the best approach to translate the source text. Besides keeping the source term as the original information, it also gave explanation with parentheses to carry out the reader understanding the meaning contained. This transferred categorized no one in linguistics one. Meanwhile, in semantics categorized into modulation, where "confirmation" is point of view the translator to give clear information to the reader by giving closely same information with the source text as the translation term, because those meaning closely same in TT. It supported by the informants were interviewed, 9 of them recognized "confirmation" also refer to the same meaning to word of tahqiq which is put in the parentheses. So, those approach impacted to the readers who understood to the meaning has translated. Moreover to the informants both the one who have been common with the Islamic terms or not.

The data 10 on the table shows the transferred from istiqomah to become "to keep oneself committed" is considered as a good work, because istiqamah literally has a meaning "acting right continuously". Hence, by transferring it into "to keep oneself committed" indicated as a person keeps himself committed to the right tract or acting right continuously. From the linguistics category, this transferred considered no one approach are used because the translator replaces istiqomah as reality in the source text with "to keep oneself committed" a corresponding reality in the target text. In the semantic side, it is categorized into modulation. Because istiqamah translated into "to keep oneself committed" is a point of view that giving by the translator. There is no equivalent term in TT, so that transferred has made is like it. Meanwhile, from the informants were asked, 7 of them responded that "to keep oneself committed" refers to someone who commits in the right tract continuously. Hence, overall, the transferred has succeeded to convey the real meaning to the all readers.

\section{Conclusions}

From the discussion it can be concluded that the data were obtained from Islamic terms taken randomly from a bilingual bulletin existed in Indonesia. From linguistics side, it found 3 data of borrowing, 1 data of transposition, and adaptation is 0 data. Meanwhile, from the semantic side, it found 5 data of modulation, 3 data of emphasis change, and 0 data of paraphrase. as the result, the most approach used to deal the meaning of the terms is semantics one. However, those approaches influenced to the transferences which were not successfully conveyed the real meaning to the informants. They who are common to the Islamic terms and otherwise got difficulties to unsderstand the transference, because the approaches were used still oriented to the word-form not to the meaning one. Semantic approaches as 
the meaning oriented is suggested to be considered to do transferring; however, the use of it in not right terms will be resulting in a missing link information originally contained in ST.

As the responses to the impact of using those approach by the readers, it is strongly suggested for the future study to be more concern not only to the classification of approaches are used but also to the relation of finding between those using and the equivalence effect by the understanding of transference not only by the reader who has a basic about the terms discussed, but also the otherwise. Ideally, the transference can be understood by the all readers as the trigger to be interesting new comer so that they can be opened their mind and curious to read the result further. The using of note to give translation context for the target reader needs to do. Translation reaches deep into the many aspects which transcend categories of understanding and knowing how knowledge is codified in a range of languages. Translation understood as an effective communication becomes a key to reach the information as the result to lead in a global order constructed on local variabilities of expressive capacity.

\section{REFERENCES}

[1] Z. Brian J., et al. "Religion and spirituality: Unfuzzying the fuzzy." Journal for the scientific study of religion: 1997. pp. 549-564.

[2] S. Khosroshahi, \& A. Sedighi, Translation of Persian Mystic Terms into English: A Case Study of Conference of the Birds by Attar. Theory and Practice in Language Studies, (2017). 7(7). pp. 552-557.

[3] B. E. Hassan, B. Translating Scientific Terminology: Examples from the Arabic versions of Two International Magazines. Mediterranean Journal of Social Sciences, (2017). 8(2). p.183.

[4] A. A. ElShiekh, \& Saleh, M. A Translation versus transliteration of religious terms in contemporary Islamic discourse in western communities. International Journal of English Linguistics, (2011) 1(2). p. 141.

[5] J. Munday, the Routledge Companion to Translation Studies. Routledge. (2009), pp. 4-10

[6]. Baker, Mona. In other words: A coursebook on translation. Routledge. (2011). pp. 82-85.

[7] G. Toury, The nature and role of norms in translation. The translation studies reader, (2000),2. pp.53-69

[8] W. Donald. "Contact and borrowing." The handbook of language contact, (2010). pp. 170-187.

[9] O. Mahmoud. "Translation procedures, strategies and methods." Translation Journal. (2007). p.8.

[10] L. Molina, \& Hurtado Albir, A.. Translation techniques revisited: A dynamic and functionalist approach. Meta: journal des traducteurs/Meta: Translators' Journal, (2002). pp. 498-512.

[11] H. Honig, Positions, power and practice: Functionalist approaches and translation quality assessment. Current Issues in Language \& Society, (1997). pp. 6-34.

[12] Ibid.

[13] B. Bruce L. Methods for the social sciences. Pearson Education Inc, United States of America, 2004.

[14] https://publikasiilmiah.ums.ac.id/.../KS\%201\%20-\%201.pdf?.

[15] Bowen, John Richard. Islam, law, and equality in Indonesia: An anthropology of public reasoning. Cambridge University Press, (2003).

[16] H. Basil, and Ian Mason.. Discourse and the Translator. Routledge.(2014) 